\title{
PERTAUTAN ANTARA ASPEK INTELEKTUAL DAN MISTIS DALAM NOVEL LANANG KARYA YONATHAN RAHARDJO
}

\author{
Sugiarti \\ FKIP Universitas Muhammadiyah Malang \\ email: atika_umm@yahoo.co.id
}

\begin{abstract}
Abstrak
Penelitian ini bertujuan mendeskripsikan pertautan aspek intelektual dan mistis dalam novel Lanang karya Yonathan Rahardjo. Penelitian menggunakan pendekatan kualitatif-fenomenologis dengan prinsip-prinsip metode analisis isi kualitatif untuk memahami pesan teks secara deskriptif. Sumber data adalah novel Lanang karya Yonathan Rahardjo dan ditunjang data hasil wawancara dengan pengarang. Data dalam penelitian ini adalah sekuen cerita yang memiliki relevansi dengan tujuan penelitian serta informasi-informasi penting yang diperoleh dari hasil penelusuran pustaka. Hasil penelitian sebagai berikut. Pertama, pertautan aspek intelektual memberikan kesadaran bahwa kecanggihan teknologi mampu mengubah sesuatu yang tidak mungkin menjadi hal mungkin, seperti rekayasa bioteknologi kehewanan. Kedua, pertautan aspek mistis bersumber pada keyakinan tradisi daerah setempat yang tidak masuk akal dan penuh dengan keanehan, tetapi masih diyakini.
\end{abstract}

Kata kunci: aspek intelektual, aspek mistis, rekayasa genetika

\section{THE CONNECTION BETWEEN THE INTELLECTUAL AND MYSTICAL ASPECTS IN LANANG, A NOVEL BY YONATHAN RAHARDJO}

\begin{abstract}
This study aims to describe the connection between the intellectual and mystical aspects in Lanang, a novel by Yonathan Rahardjo. It employed the qualitative phenomenological approach using principles in qualitative content analysis to understand text messages descriptively. The data sources were Lanang and the results of interviews with the author. The data comprised the story sequence relevant to the research objectives and important information obtained from literature review. The findings are as follows. First, the intellectual aspect stimulates awareness that the technology sophistication is capable of changing what is impossible into what is possible, such as animal biotechnology engineering. Second, the mystical aspect originates from beliefs in a local tradition that may be illogical and full of weirdness but people still believe them.
\end{abstract}

Keywords: intellectual aspect, mystical aspect, genetic engineering

\section{PENDAHULUAN}

Sastra merupakan cerminan sosial yang banyak mengungkapkan peristiwaperistiwa yang ada dalam masyarakat. Begitupula dengan novel yang seringkali menceritakan liku-liku kehidupan manusia yang terjadi dalam realita. Sastra tidak dapat dilepaskan dengan peristiwa realitas sosial. Sastra menyatu dengan realitas sosial sesuai dengan kehendak pengarang. Pengarang memiliki cara tersendiri dalam menggambarkan realita dalam bentuk karya sastra (novel). Pandangan/pemikiran pengarang akan me- 
warnai realitas peristiwa yang dihadirkan dalam karya. Demikian pula pengarang dalam melakukan proses kreatif akan dipengaruhi sesuatu yang mempribadi dalam dirinya serta kecermatannya dalam melihat, mendengar, merasakan, serta menghayati sesuatu yang terjadi dalam realitas. Oleh karena itu, tidak salah jika pengarang dalam mengungkapkan proses kreatif dalam bentuk novel telah mampu menghasilkan sesuatu yang lengkap dan menyeluruh atas peristiwa yang terjadi dalam masyarakat. Pada dasarnya, seluruh kejadian dalam karya, bahkan juga karya-karya yang termasuk ke dalam genre yang paling absurd pun merupakan prototipe kejadian yang pernah dan mungkin terjadi dalam kehidupan seharihari (Ratna, 2013:35).

Masalah munculnya sebuah karya sastra besar tidak lain adanya latar belakang sosial yang mendukung karya tersebut. Karya sastra ini sangat berhubungan kuat dengan pengaruh latar belakang sosial pengarang, seperti gagasan-gagasan, ide-ide, dan aktivitas-aktivitas pengarang yang menjadi struktur dalam karya sastra dalam bentuk pandangan dunia. Maka dari itu, setiap karya sastra memiliki asal-usul penciptaan yang biasa dikenal dengan genetik. Saraswati (2003:10) mengatakan, karya sastra itu mempunyai asal-usulnya (genetik) di dalam proses sejarah suatu masyarakat

Menurut Durkheim, sastra berfungsi memberikan pengalaman kepada anggota masyarakat akan adanya sebuah realitas yang melampaui batas-batas dunia pengalaman langsung individual (Faruk, 2013: 6). Namun demikian sastra juga mengungkap sesuatu yang tidak dapat dirasionalkan oleh pikiran manusia. Sesuatu yang mistis seringkali diungkapkan pengarang dengan pemahaman bahwa dalam kebudayaan masyarakat antara ada dan tiada tidak dapat dipisahkan. Pengarang sebagai penghadir sastra selalu berpikir keras untuk merenungkan sesuatu yang terjadi dengan mengkaitkan dirinya bersama masyarakat.

Sebagai ciri khas kehidupan sosial interaksi menandai hubungan antara seniman dengan latar belakang sosialnya. Tipe hubungan seniman dengan masyarakat, seperti juga para ilmuwan, pada dasarnya sama dengan pola-pola hubungan sosial yang lain. Pola-pola hubungannya tidak ditentukan oleh status sebagai seniman atau ilmuwan, melainkan oleh jaringan peranan, jaringan hubungan sebagai aspekaspek dinamis status tersebut (Ratna, 2013: 76). Struktur sosial ditentukan melalui interaksi sosial, perangkat sistem simbolis, sistem peranan dan harapan, yang kemudian dikonstruksikan ke dalam polapola institusionalisasi, bukan sebaliknya. Karya sastra adalah respons-respons interaksi sosial melalui personalitas seniman, bukan di dalam personalitas seniman (Ratna, 2013:77).

Pengarang dalam menciptakan karya sastra selalu akan dipengaruhi oleh latar belakang sosial budaya masyarakat, pemikiran serta ekspresi pengarang. Nilainilai dalam karya sastra merupakan hasil ekspresi dan kreasi estetik sastrawan yang ditimba dari kebudayaan masyarakatnya. Persoalan kebudayaan tidak dapat dilepaskan dengan perkembangan ilmu pengetahuan dan teknologi. Pola pikir pengarang akan mengikuti perkembangan Ipteks. Ipteks dapat memperngaruhi pemikiran pengarang dalam menghasilkan karya sastra. Yonathan Rahardjo sebagai pengarang mersepon Ipteks sebagai inspirasi dalam pembuatan karya sastra. Hal ini disadari bahwa perkembangan teknologi secara khusus bioteknologi telah menyatu dengan pola pikir masyarakat yang menekuni bidang tersebut. Rekayasa bioteknologi akan memunculkan produk pikiran manusia yang nyata. Produk tersebut bagi kehidupan masyarakat dapat berdampak positif maupun negatif.

Dampak positif perkembangan teknologi akan bermanfaat bagi manusia, se- 
dangkan dampak negatif akan berpengaruh signifikan pada kehidupan manusia baik secara langsung maupun tidak langsung. Dalam novel Lanang berupaya untuk mengemukakan keduanya dalam sebuah pilihan untuk dipikirkan. Akan tetapi kenyataannya mereka terkadang memilih hal-hal yang tidak rasional (mistis) untuk kepentingan dirinya di satu sisi dan rasional di sisi lain. Sisi-sisi tersebut merupakan sebuah pertautan yang dipadu sehingga menjadi narasi cerita yang menarik.

Menurut Roland Barthes (dalam Rafiek, 2010:103) mitos dapat hidup dalam suasana tindakan revolusioner dengan cara berkhayal. Oleh karena itu memiliki karakter sadar diri dari fisiknya yang kaku, bercampur baur dan sederhana sehingga secara terbuka mempengaruhi perilaku intelektual dengan pondasi-pondasi politis. Sesungguhnya mitos dalam sastra selalu berkembang karena kreativitas pengarang. Antara intelektual dan yang mistis terkadang sulit untuk dibedakan secara jelas.Sastra mampu merekam yang intelektual dan mistis dan menyandingkannya sehingga menjadi sesuatu yang menarik. Mitos ini tidaklah dapat digambarkan melalui objek pesannya, tetapi melalui cara pesan tersebut.

Kenyataannya, pengetahuan yang terkandung dalam sebuah konsep mistis adalah pengetahuan yang rancu dan kabur, terdiri atas berbagai asosiasi tanpa bentuk. Konsep sama sekali bukanlah esensi abstrak dan murni. Mistis adalah pemadatan tanpa bentuk, tidak stabil dan samar yang kesatuan dan koherensinya sangat tergantung pada fungsinya (Rafiek, 2010:106). Dalam mitos tidak menyembunyikan dan tidak memamerkan apapun. Mitos mampu membuat konsep yang dimaksudkan menjadi lebih menarik dan menggugah. Dengan demikian dapat dikatakan bahwa sesuatu yang mistis akan mampu mempengaruhi seseorang untuk berpikir dengan cara yang berbeda dengan mengkaitkan sesuatu yang ada di luar rasio manusia.

Mistisisme adalah kepercayaan bahwa kebenaran tertinggi tentang realitas hanya dapat diperoleh melalui pengalaman intuitif suprarasional, bahkan spiritual, dan bukan melalui akal (rasio atau reason) logis belaka. Mistik atau mistisisme merupakan paham yang memberikan ajaran yang serba mistis (misal ajarannya berbentuk rahasia atau ajarannya serba rahasia, tersembunyi, gelap atau terselubung dalam kekelaman) sehingga hanya dikenal, diketahui atau dipahami oleh orang-orang tertentu saja, terutama sekali penganutnya (Gabiz, 2013:2).

Kebudayaan sebagai hasil cipta, karsa dan karya manusia seringkali hanya dipahami tidak lebih dari sebuah konstruksi suatu kolektivitas tertentu, bukan sesuatu yang berbasis pada kenyataan material yang bersifat tetap dan niscaya. Semuanya menjadi tidak lebih dari sebuah rule of the game. Begitu juga kesastraaan. Segala bangunan konseptual dan pemaknaan mengenai kesastraan, segala pembedaan yang diberikan antara sastra dengan bukan sastra, antara fakta dengan fiksi, antara sastra tinggi dengan sastra rendah, dan sebagainya, bukanlah bangunan yang kokoh, yang berdiri di atas fondasi fisik yang bersifat tetap dan niscaya, melainkan di atas sebuah bangunan mental yang ringkih, labil, mudah dan dapat berubah, dan bahkan dapat mengandung kepentingan sepihak dari seseorang ataupun sekelompok orang ( Faruk, 2013:7).

Pada perspektif sosial budaya bangunan kesastraan selalu terkait dengan bangunan material dan immaterial yang memberikan pengaruh cukup signifikan. Bangunan tersebut terkadang menjadi ajang pertaruhan bagi sebagian masyarakat untuk menyampaikan sebuah ideologi dan atau kepentingan-kepentingan tertentu. Hal ini terjadi karena persoalan kehidupan semakin komplek dan perkembangan zaman selalu berubah mengikuti perubahan waktu. 
Derajat rasionalitas yang tinggi merupakan tanda perkembangan globalisasi masyarakat modern. Dalam artian kegiatan-kegiatan terselenggara berdasarkan nilai-nilai dan pola-pola yang objektif ( $\mathrm{im}$ personal) dan efektif (utilitarian)daripada yang sifatnya primordial, seremonial atau tradisional. Derajat rasionalitas yang tinggi itu digerakkan oleh perkembanganperkembangan ilmu pengetahuan dan teknologi. Oleh karena itu, ilmu pengetahuan dan teknologi seringkali disebut sebagai kekuatan pendorong (driving force) bagi proses modernisasi. Dengan derajat rasionalitas yang tinggi itu, maka berkembang antara lain ciri-ciri yang kurang lebih berlaku umum yaitu tindakan-tindakan sosial, orientasi terhadap perubahan dan berkembangnya organisasi dan diferensiasi (Gabiz, 2013:1).

Yonathan Rahardjo mampu memadukan realitas masyarakat disajikan dalam rangkaian cerita yang menarik. Sebagai pengarang yang memiliki latar belakang pendidikan kedokteran, Yonathan berhasil menciptakan novel yang multitema bahkan sebagaimana yang dikatakan oleh penyair Medy Loekito (dalam Rahardjo, 2008: xiv) saat memberikan komentar tentang novel ini.

"Membaca Lanang seakan berjalan di depan deretan etalase toko. Ada berbagai macam hal dipajang, ada yang cantik, ada yang kotor. Mulai dari urusan koperasi, manajemen, LSM, karakter flora-fauna, profesi dokter hewan, mistik, agama, kecelakaan, kloning laboratorium, peternakan, libido, seks, penipuan, pelacuran dan lain sebagainya. Pada intinya, sepenggal bagian hidup ini menjadi begitu ruwetnya di dalam Lanang. Jika dijabarkan, mungkin novel ini bisa menjadi ensiklopedia berisi berbagai pengetahuan dan kasus (Rahardjo, 2008: xiv).
Pola pikir pengarang dalam memadukan persoalan-persoalan intelektual dan mistik menyebabkan karya tersebut benarbenar dekat dengan realitas kehidupan masyarakat. Masyarakat pada zaman modern terdapat gejala untuk membuat perimbangan antara yang intelek dan yang mistik. Bagi pengarang kedua hal tersebut telah menyatu dengan kehidupan masyarakat dan gejala tersebut berlaku pada masyarakat pada umumnya. Fenomena orang sakit, memang banyak juga dokter yang mampu mengobati orang sakit.Akan tetapi, kenyataanya mereka juga masih berobat ke alternatif yang secara rasional terkadang tidak masuk akal, namun mereka meyakininya.

Penulis meyakini bahwa proses kreatif terjadi karena terjadi kegelisahan akan sesuatu tentang persoalan kehidupan. "Kegelisahan penulis sejak proses penciptaan novel Lanang adalah, novel ini merupakan sebuah novel genre multidimensi pertama di dunia karya bangsa Indonesia yang bakal menggoncang dan mengukuhkan keberadaan pembaca sebagai makhluk kompleks dan multidimensi dalam hubungan dengan diri sendiri, sesama manusia, makhluk lain dan sistem-sistem yang ada". Penulis yakin bahwa pembaca memiliki horizon yang cukup memadai sehingga berdampak pada resepsi atas karya yang telah dibaca (Rahardjo, 2013: 5)

Dalam proses pembacaan itu, pembaca akan menemukan diri sendiri dengan nilai-nilai mikro, menengah dan makro yang mempengaruhinya. Pada gilirannya pembaca secara jujur melakukan segala sesuatu secara mikro, menengah dan makro berdasar kemurnian pertimbangan dan hati nuraninya. Pembacaakan mendapatkan manfaat lain yang berkelanjutan dan terus-menerus. Novel genre multidimensi ini menjadi kegelisahan penulis untuk terus mencipta tulisan-tulisan novel yang lain seperti yang sudah terbit novel "Taman Api" dan "Wayang Urip" yang semuanya senantiasa penulis evaluasi 
guna tidak berhentinya proses kreatif (Rahardjo, 2013:5)

Melihat realitas dalam sastra yang dituangkan dalam novel Lanang karya Yonathan Rahardjo maka masalah yang diteliti mencakup dua hal yaitu: (1) pertautan aspek intelektual dalam novel Lanang karya Yonathan Rahardjo; (2) pertautan aspek mistis dalam novel Lanang karya Yonathan Rahardjo. Kedua aspek ini menjadi penting yang dapat digunakan untuk melihat proses kreatif pengarang dalam menghasilkan karya sastra di satu pihak dan melakukan telah teks di pihak lain.

\section{METODE}

Penelitian ini menggunakan pendekatan kualitatif-fenomenologi dengan prinsip-prinsip metode analisis isi kualitatif yang biasa digunakan untuk memahami pesan dari wacana atau teks. Sumber data penelitian adalahnovel Lanang karya Yonathan Rahardjo dan ditunjang dengan data yang diperoleh dari hasil wawancara dengan pengarang untuk mempertajam konsep. Data dalam penelitian berupa sekuen cerita yang memiliki relevansi dengan tujuan penelitian serta informasiinformasi penting yang diperoleh dari hasil penelusuran pustaka maupun hasil wawancara kepada pengarang. Analisis dilakukan secara melingkar, timbal balik, dalam rangka memperoleh pemahaman arti yang mendalam. Langkah-langkah analisis data meliputi: (1) pembacaan secara kritis-kreatif terhadap seluruh data, (2) pengkolaborasian terhadap kerangka (frame) pikir pengarang, (3) penyajian data yang terdiri atas identifikasi dan klasifikasi data berdasarkan domain masalah, dan (4) penafsiran terhadap seluruh data, serta penyimpulan.

\section{HASIL DAN PEMBAHASAN}

Dalam novel Lanang pengarang berupaya untuk menyandingkan antara intelektual dan mistis sesuai dengan konteks yang ada di masyarakat. Keseluruhannya disusun secara padu untuk menghadirkan teks yang memenuhi kadar kesastraan. Teks yang dihadirkan memiliki kekuatan untuk membawa pemikiran pembaca untuk menyadari bahwa intelektual dan mistis bukanlah suatu dikotomi yang harus dipisah secara tegas. Akan tetapi, keduanya merupakan satu kesatuan yang saling melengkapi dalam menyikapi perkembangan zaman. Suatu saat ketika orang sudah jenuh dengan pola rasionalitas atas dasar intelektual maka mereka berkecenderungan mencari yang mistis. Hal ini sejalan dengan pola pikir postmodernisme yang membawa pemahaman dan berbagai konsep yang berkaitan dengan manusia dengan keseluruhan keberadaannyatidak semata-mata dilihat melalui satu dimensi (Ratna, 2008: 389). Oleh sebab itu, tidak dapat dihindari bahwa dalam sastrapun juga mengungkap persandingan antara intelektual dan mistis dalam satu kesatuan yang saling melengkapi. Pada pembahasan berikut ini berupaya mengungkapkan bagaimana sesungguhnya pertautan antara intelektual dan mistis itu dapat dipahami melalui novel Lanang karya Yonathan Rahardjo.

\section{Pertautan Intelektual dalam Novel- Lanang Karya Yonathan Rahardjo}

Kecermatan dan kepiawian Yonathan dalam meramu cerita untuk menghadirkan perkembangan bioteknologi khususnya rekayasa genetika mampu mewarnai narasi cerita dalam novel dapat diperhatikan melalui kutipan berikut

Gunungan hitam timbul! Menyundul salah satu kayu ranjang dan kasur. Menyembul sesuatu mirip kepala. Lebih tampak warna hitam. Uh! Baunya busuk, namun tertutupi bau $\mathrm{Pu}-$ tri dan Lanang. Benda itu bergerak. Menarik diri dari ranjang yang telah disundul dan dikacaukan (Rahardjo, 2008: 10). 
Kecanggihan teknologi melalui rekayasa genetika yang dilakukan oleh manusia melahirkan hewan yang tidak lagi seperti aslinya. Berbagai perubahan tercipta sehinga akan sulit dikenali hewan apa sebenarnya yang dihasilkan. Hal ini dibuktikan dengan kutipan di atas. Babi hutan yang pada awalnya tidak memiliki bau busuk, setelah dilakukan rekayasa genetika melahirkan babi yang baunya busuk luar biasa. Dari segi fisik, babi hutan hasil rekayasa genetika memiliki tubuh yang jauh lebih besar dan lebih hitam serta memiliki sifat yang ganas. Sebuah realitas yang dibenturkan dengan kecanggihan-kecanggihan teknologi terkadang ada yang tidak rasional menjadi rasional seiring dengan peradaban manusia.

Latar belakang pendidikan pengarang memiliki pengaruh terhadap penciptaan novel Lanang. Hal ini dapat diperhatikanpada kutipan berikut.

Aku masih akan bangga pada sikap yang membuktikan secara ilmiah dengan menunjukkan hasil pemeriksaan biologi molekuler bahwa DNA pada vurus memang benar jelas penyakitnya, bukan ngomong biangnya makhluk aneh macam tahayul Burung Babi Hutan jadi-jadian (Rahardjo, 2008: 188).

Kutipan di atas menggambarkan bahwa yang dialami tokoh dalam cerita pengarang dengan senyatanya memasukkan istilah-istilah yang berkaitan dengan dunia kedokteran hewan terkait dengan interaksi berbagai sistem sel, termasuk interaksi DNA, RNA, dan sistem protein, serta bagaimana interaksi tersebut diatur. Pada dasarnya, pascamodernisme mengembangkan dan menyebarkan gagasan dan tindakan yang dapat memberikan kesadaran pada semua orang bahwa apa yang diyakini manusia selama ini tak lebih daripada permainan belaka yang ditegakkan atas dasar sebuah aturan per- mainan yang disepakati oleh sekelompok orang dan tidak disepakati oleh sekelompok orang lainnya yang mempunyai aturan permainan yanglain pula(Faruk, 2013:8).

Makhluk berwujud babi hutan itu beringsut ke posisi ancang-ancang lagi. Di bagian atas dan bawah moncongnya yang menjorok ke depan dengan dua lubang hidung besar melingkar, muncul taring berkilat. Menyeringai dingin (Rahardjo, 2008:11).

Hasil rekayasa genetika seekor babi hutan melahirkan sifat bengis dan kejam. Keliarannya semakin nyata ketika berhadapan dengan manusia yang dianggap sebagai musuh. Hal inilah yang dikhawatirkan akan menjadi pengganggu elektabilitas alam. Hasil rekayasa genetika babi hutan dikhawatirkan akan mengganggu hewan-hewan lain bahkan manusia sebagaimana keinginan manusia yang melakukan rekayasa tersebut untuk memuaskan ambisinya.

Semakin ia maju semakin tampak macam apa benda itu, kecil panjang punya pangkal di lipatan paha. Entah apa warnanya sesungguhnya lantaran kegelapan masihlah berkuasa. Oh! Pikiran dokter hewan datang pada Lanang. Benda kecil panjang itu penis yang punya lima ujung seperti belalai. Persis organ kelamin binatang Tapir selagi menegang dan merejan (Rahardjo, 2008:12).

Tapir dan Babi hutan merupakan dua jenis hewan yang berbeda dan memiliki kekhasan masing-masing, akan tetapi karena kecanggihan teknolongi dengan adanya rekayasa genetika menjadikan Tapir dan Babi hutan tidak dapat dilihat dengan jelas perbedaan dan persamaanya. Hal itu terlihat jelas pada penggambaran organ kelamin binatang yang sangat berbeda dengan binatang lainnya yaitu memiliki lima ujung kelamin. Ciri kedua hewan tersebut melebur menjadi satu kesatuan dan tidak jelas. 
“Hm... bisa jadi itu makhluk hasil teknologi perkawinan genetik antara babi hutan dan burung. Ciri kedua binatang ini jelas terlihat pada sosoknya." (Rahardjo, 2008: 33).

Hewan transgenik merupakan perpaduan dua hewan atau lebih yang dikawinkan secara silang dan menghasilkan spesies hewan baru yang tidak lagi sama dengan hewan asalnya, akan tetapi hewan hasil trangenik memiliki ciri-ciri yang sama dari asal hewan yang disilangkan. Begitu juga dengan makhluk aneh yang mendatangi dokter Lanang dan istrinya pada saat akan melakukan hubungan intim. Makhluk tersebut memiliki sayap dan memiliki tubuh seperti babi. Sayap yang ada pada kakinya menandakan bahwa ada unsur burung dalam tubuh hewan tersebut. Kecerdasan manusia untuk menciptakan teknologi sehingga menghasilkan sesuatu yang berbeda.

Hasil rekayasa genetika pada hewan dapat menghasilkan hewan baru yang bentuk dan rupanya sangat jauh berbeda dari hewan kebanyakan, bahkan lebih seram. Sesutau yang bagi orang awam tidak mungkin terjadi, tidak berlaku pada manusia yang memiliki intelektualitas tinggi dan yang menguasai teknologi. Seekor burung dapat dikawinkan dengan seekor babi, sehingga akan menghasilkan hewan yang sangat aneh. Hal ini memperkuat bahwa kaum intelektual bagi Gramsci sebagai strata yang melakukan tugastugas spesifik dalam aspek produksi, kebudayaan, dan politik. Intelektual tidak ditandai dengan ciri berpikir instrinsik akan tetapi berdasarkan fungsi dan peran yang mereka jalankan ( Anwar, 2012: 83).

Babi hutan kebanyakan tidak memiliki sayap, karena dikawinkan dengan burung menyebabkan muncul sayap di kaki babi tersebut. Hal ini dapat dilihat pada kutipan berikut.
Babi hutan. Bermoncong berbulu. Bermata liar. Tubuh penuh bulu hitam. Berkaku empat. Di kaki depanya menguncup bulu-bulu sayap. Begitu jelas wujud makhluk itu (Rahardjo, KTRG. 2008: 81).

Rekayasa genetika hewan antara babi hutan dengan seekor burung yang dilakukan sekelompok manusia tidak bertanggung jawab menghasilkan varian baru yang mengerikan. Babi hutan yang kotor dan memiliki bulu hitam semakin menyeramkan ketika bulu-bulu sayapnya tumbuh dan matanya semakin liar.

Selain sayap yang tidak lazim ada pada seekor babi, terdapat pula keganjilan akibat dari rekayasa genetika hewan, yakni adanya alat kelamin seperti kelamin yang ada pada tubuh manusia (laki-laki).

Tertangkap oleh mata putri, yang berseribu makna pandang, di bawah tubuh gendut mahkluk ini menggantung sebuah ujung runcing, berpentul, bulatan kecil dari suatu mungil panjang berpangkal di lipatan paha (Rahardjo, 2008: 83).

Kutipan di atas menggambarkan dengan jelas bahwa anatomi tubuh dari hewan hasil rekayasa genetika berbeda dari hewan kebanyakan, ada yang menyerupai bagian tubuh manusia. Hal ini dikarenakan rekayasa genetika tidak hanya dapat dilakukan antara hewan berbeda jenis, melainkan dapat pula dilakukan antara hewan dengan manusia.

Mengingat semua pembicaraan mereka yang didominasi oleh celoteh Lanang, Dewi tersenyum simpul, sementara genggaman tangannya pada Lanang semakin erat. Namun dalam batinnya tergores rasa makin sempurna pemindahan energi dan genetik Lanang baginya. Tak ubahnya perkembangan teknologi yang makin pesatnya yang sangat dikenalnya. 
Pikirnya, gen dari hewan yang berbeda jenisnya dapat dipindahkan, bukan hanya dari sapi ke sapi. Tetapi bisa dari manusia ke sapi, ke domba, ke babi, dan ke berbagai makhluk lainnya (Rahardjo, 2008: 258).

Dampak kecanggihan teknologi rekayasa genetika dapat mengancam keseimbangan alam, sebab gen dari hewan tidak saja dapat dicampurkan dengan sesama hewan melainkan juga pada manusia. Hal inilah yang paling dikhawatirkan. Dengan demikian, akan tercipta kerusakan lingkungan sebab ulah manusia yang terlalu berambisi dengan nafsu keduniawiannya. Bagi manusia yang tidak bertanggung jawab, kecanggihan teknologi dapat menyebabkan manusia semakin rakus dan tidak terkendali ambisinya. Setiap keinginan akan diwujudkan dengan cara apapun, tidak lagi peduli dampaknya terhadap alam dan isinya.

Begitu membuka kotak peralatan, di situ terdapat satu wujud makhluk kecil sedang mempermainkan makhluk yang lebih kecil. Sosok itu menoleh ke arahnya. Menyeringai. Bisa tampak dalam gelap. Giginya sangat runcing, menyala terang hijau seperti fosfor. Tubuhnya mirip nyamuk akan tetapi lebih besar dari kebanyakan tubuh nyamuk. Bersayap transparan dengan kaki-kaki berbulu pendek. Kepalanya bulat seperti kepala tupai. Pada gigi runcing nyamuk berkepala tupai itu terdapat bercak darah (Rahardjo, 2008: 212).

Hasil dari kecanggihan rekayasa teknologi genetika mampu menghasilkan jenis hewan baru yang jauh berbeda dari bentuk aslinya. Seekor nyamuk dapat mengubah ukuran menjadi lima kali lebih besar dari aslinya sesuai dengan keinginan manusia yang sengaja menciptakannya. Dua hewan yang memiliki kekhasan berbeda diciptakan menjadi satu, sehingga akan berdampak luar biasa di segala sisi. Hal itu sejalan dengan ungkapan pengarang (hasil wawancara 19 September 2013) bahwa bakteri patogen adalah bakteri berbahaya yang dapat menimbulkan penyakit, ada di dalam tubuh makhluk hewan (hewan/ manusia). Induk semang (dalam bahasa Inggris= host) berarti tuan rumah atau pembawa bakteri patogen itu pada tubuhnya. Bakteri itu ada pada induk semang berarti bakteri hidup di dalam tubuh makhluk hidup hewan atau manusia yang berfungsi sebagai tuan rumah atau host itu. Pada induk semang antara, induk semang ini tidak sakit karena bakteri itu tapi dia dapat membawa dan menularkannya ke makhluk hidup (hewan/manusia) lain. Dengan demikian trangenerasi dari hewan ke manusia itu pada kenyataannya tidak dapat dihindari.

Pola pikir pengarang nampak nyata bahwa sesungguhnya intelektualitas yang dimilikinya berkontribusi pada proses kreatif yang dimunculkan melalui narasi cerita. Kecerdasan pengarang untuk memasukkan inteletualitas dalam karya sastra merupakan suatu upaya melahirkan bahwa dalam fiksi permasalahan dapat digali dari perkembangan pengetahuan dalam bentuk fiksi pengetahuan (science fiction).

\section{Pertautan Aspek Mistis dalam Novel Lanang Karya Yonathan Rahardjo}

Pada kenyataannya persoalan mistis sering menyatu dengan kehidupan masyarakat. Ritual mistis dijadikan sebagai penciptaan situasi atau kondisi lain yang dilakukan oleh manusia. Yonathan sebagai pengarang secara pribadi tidak menjalankan ritual mistis tersebut. Akan tetapi dengan melihat pengalaman yang terjadi di masyarakat dan sering melihat kenyataan yang ada maka persoalan mistis menjadi salah satu bagian yang memberikan inspirasi pengarang atas karya yang dihasilkan. Mistis bagi pengarang merupakan suatu realita masyarakat yang su- 
dah mempribadi pada sebagian kehidupan manusia. Ia mampu menyatukan dirinya dengan keyakinan yang mampu memberikan kekuatan magis. Hal ini dapat diperhatikan pada kutipan berikut.

Dari sekujur kedua kaki depannya muncul bulu-bulu, sayap, mengembang. Makhluk itu tanpa ancangancang melompat, melayang, terbang. Hilang dalam kekelaman malam. Bulan di langit tak kuasa menerangi jejaknya.Angin masih berembus dingin. Terdengar gaung," Huh..Huh!!! di angkasa (Rahardjo, 2008: 13).

Perubahan bentuk sang makhluk yang memiliki kekuatan untuk terbang dan menghilang dalam remang cahaya bulan, merupakan penggambaran kekuatan mistis dari suatu daerah yang diketahui pengarang. Makhluk yang berbulu, bersayap dan bisa terbang serta tidak dapat terlihat dalam cahaya jelas adalah makhluk yang berada atau tumbuh dalam dunia suprarasional dan sulit ditemui dalam dunia nyata.

Hal ini juga dapat dilihat dari kutipan di bawah ini.

"Kasus kematian sapi ini pasti ada hubungannya dengan munculnya makhluk aneh di rumahku."

"Makhluk aneh apa?"

"Malam sebelum kutahu kematian sapi-sapi itu, aku baru saja kedatangan makhluk aneh berwujud seperti babi hutan tapi bersayap!" (Rahardjo, 2008: 31).

Kedatangan hewan aneh di rumah dokter Lanang pada malam setelah dia membantu persalinan sapi perah milik salah satu peternak, dikaitkan dengan wabah penyakit yang menimpa ribuan sapi perah. Pemikiran seperti ini menjadi tanda bahwa manusia yang memiliki intelektual tinggi seperti dokter Lanang, masih percaya pada hal-hal gaib yang yang tidak dapat dicerna oleh akal. Sayangnya, pemikiran tersebut terlanjur menguasai hampir seluruh penduduk yang memiliki sapi perah yang terkena wabah penyakit. Selain itu, wawancara dengan pengarang (19 September 2013) problema tersebut terinspirasi ketika semua tentang flu burung masih awal terjadi di Indonesia pada tahun 2003-2006.

Terkait dengan babi, saat itu yang baru saya jumpai masih berupa kenyataan bahwa babi merupakan hewan yang dapat menularkan flu burung dari unggas ke manusia karena kesamaan kondisi tubuhnya dengan manusia. Di dalam perkembangan virus dalam tubuh babi bisa mengubah sifat virus yang semula hanya bisa menyerang unggas menjadi bisa menyerang mamalia terutama manusia. Sampai suatu titik masa kabar virus Flu Burung menyerang babi belumlah pernah dijumpai. Namun pada 2005 terungkap seratus ekor babi sudah kedapatan di dalam tubuhnya virus Avian Influenza $\mathrm{H} 5 \mathrm{~N} 1$, virus ganas AI yang dikenal di Indonesia seperti halnya Cina. Jadi saat itu belum tentang virus H1N1.

Makhluk aneh yang telah mendatangi dokter Lanang telah benar-benar menimbulkan kegelisahan dalam hatinya. Pikirannya sebagai mahasiswa yang setiap harinya bergelut dengan pemikiran ilmiah tidak percaya bahwa makhluk tersebut merupakan makhluk jadi-jadian. Tetapi jika benar makhluk yang menyeramkan tersebut hasil dari rekayasa genetika, kemungkinan tersebut sangat kecil, mengingat tempatnya bekerja hanyalah pegunungan yang hanya berisi para peternak sapi perah.

Tak dapat dipungkiri Lanang gelisah. Mengingat kembali apa yang dilihatnya. Sosok binatang yang tak diundang itu mirip babi hutan. Tapi punya sayap seperti burung, memang ada kemungkinan itu makhluk transgenik, kalau bukan hewan jadi-jadian sebagaimana dikenal di masyarakat tradisionalnya (Rahardjo,TM. 2008: 33). 
Ketika dunia sudah dikuasai teknologi dan manusia mampu hidup hanya dengan mengandalkan intelektualitas, dokter Lanang serta teman-temannya masih saja mempercayai keberadaan seorang dukun. Mereka percaya bahwa dukun lebih hebat dalam menangani wabah penyakit yang sedang menyerang ribuan sapi perah di nusantara. Pola pikir ilmiah para dokter hewan dan pegawai koperasi telah luntur akibat lelahnya terhadap pencarian solusi yang dapat mengusir wabah penyakit yang menyerang sapi perah. Hal itu dipertegas dari wawancara dengan pengarang (19 September 2013) yang mengatakan bahwa inspirasi cerita mistik dari berbagai cerita masyarakat lokal yang dia dengar dan baca di berbagai buku dan media massa sejak kecil, dan juga ditonton di film-film. Meskipun masing-masing tidak sama persis, ada banyak kemiripan dan pada hakikatnya sama. Pengarang juga menjumpai beberapa orang yangmempunyai alat-alat untuk upacara yang dikatakan mistik. Saat menulis novel Lanang dia tidak melihat secara langsung orang melakukan ritual mistik itu, namun dia meyakini banyak yang melakukan hal tersebut, dan sekarang saya sudah melihat secara langsung. Hal ini dapat dilihat dari kutipan berikut.

"Saya tegaskan, Pak Rajikun adalah seorang dukun hewan" Semua mata saling berpandangan. Mulut terkunci. "Beliau, dukun hewan Rajikun sudah mendapatkan obat Ekstra Ampuhyang hebat," bagai angin puyuh yang mendesis di belantara suara ketua koperasi itu. "Terdiri dari seribu kuman," Rajikun yang merasa menang harus di atas angin menyahut (Rahardjo,2008: 102).

Profesi dukun dekat sekali dengan kemistisan dan kebohongan. Sebab untuk menjadi seorang dukun tidak memerlukan gelar sarjana maupun doktor. Cukup mengandalkan kepercayaan dari orang- orang yang ada di sekitarnya. Demikian pula yang terjadi dengan seorang yang bernama Rajikun yang mengenalkan dirinya sebagai dukun hewan. Apapun ia lakukan, termasuk membohongi masyarakat dengan mengatakan bahwa dirinya mengetahui sebab musabab kematian ribuan sapi perah milik para peternak. Sebagai dukun, Rajikun juga memfitnah dokter Lanang dengan mengatakan bahwa dokter Lanang yang gemar melakukan hubungan intim dengan selain istrinya sebagai biang kerok kematian sapi-sapi tersebut. Dari sini dapat diketahui bahwa tradisi dimaknai sebagai sesuatu yang sudah lama. Di lain pihak, hal tersebut dipahami sebagai kekuatan yang memberikan identitas dan daya lawan masyarakat dalam menghadapi berbagai kekuatan yang datang dari luar (Faruk, 2001: 15).

"Kuman-kuman itu disedot dari ribuan gadis, wanita, perempuan, janda, pelacur yang secara tidak langsung menjadi penyebab kematian sapi perah!" "Secara tidak langsung?"

"Ya, sebab, kuman itu membutuhkan perantara untuk menyebar. Sampai saat ini perantara itu masih bergentayangan menyebarkan kuman-kuman itu pada sapi-sapi perah. Meski ia tidak selalu kelihatan ia tetap bekerja mencabut setiap nyawa sapi perah yang ada"(Rahardjo, 2008: 102).

Jiwa intelektualitas para dokter hewan dan juga petugas koperasi serta para peternak benar-benar telah sirna akibat terpengaruh dari kalimat-kalimat yang dilontarkan oleh seorang dukun. Para dokter dan ahli kesehatan hewan belum mampu menemukan penyebab adanya wabah penyakit yang menyerang sapisapi tersebut. Hal ini segera dimanfaatkan oleh dukun hewan Rajikun untuk mencapai ambisinya dengan mengatakan kebohongan demi kebohongan yang dibungkus dengan kemistisan. Gadis, 
perempuan, janda, dan pelacur dikatakan memiliki kuman yang bergentayangan dan dapat disedot sebagai penyebab kematian sapi jelas merupakan pandangan dukun sendiri yang tidak dapat dibuktikan kebenarannya. Perkataan itu jelas berindikasi bahwa kaum perempuanlah sumber dari marabahaya dan sumber dari kekuatan mistis.

"Untuk itu satu-satunya cara mencegah penyebaran kuman melalui perantara itu adalah dengan ditangkapnya makhluk jahat yang jadi perantara kematian sapi perah itu".

"Apa makhluk jahat itu?"

"Binatang yang wujudnya sangat aneh," kata Dukun Hewan Rajikun seraya berdiri. Tersenyum simpul.

"Burung Babi Hutan," tenang berwibawa lelaki ini menjawab (Rahardjo, 2008. 103).

Kutipan di atas menjadi bukti bahwa hal-hal mistis selalu dengan gencar dilontarkan oleh dukun hewan Rajikun untuk membuat masyarakat percaya dengan profesinya. Ia melakukan apa saja asalkan ambisinya dapat tercapai. Termasuk dengan membuat statemen bohong mengenai penyebab matinya ribuan sapi perah.

Mendapat gempuran demi gempuran dari rekan sesama dokter hewan dan juga para pegawai koperasi menjadikan pemikiran ilmiah dokter Lanangpun samar. Kelelahannya mencari solusi terhadap kasus matinya sapi perah menjadikan pikirannya nyaris dikalahkan dengan halhal mistis. Di tambah berbagai hal yang dilihatnya di tempat praktik doktor Dewi (mantan pacarnya) seakan-akan menyempurnakan keputusasaannya. Hal ini dapat dilihat dari kutipan berikut.

Sebenarnya nyamuk berkepala tupai tadi ada atau tidak ada? Sebenarnya, burung babi hutan itu sungguh-sungguh ada atau sekadar bayang-bayang semata? Mereka roh? Hantu? Atau apa? Zat? Seperti nyamuk berkepala tupai itu? Mengapa kalau aku hampir menangkap tiba-tiba burung babi hutan itu lenyap begitu saja? (Rahardjo,TM. 2008: 217).

Ketika sebuah forum seminar yang seharusnya membahas masalah-masalah ilmiah dan dapat dibuktikan pula secara ilmiah, justru menjadi ajang pamer dan pemerkosaan logika oleh kemistisan. Hal ini disebabkan para pembicara dalam seminar bergengsi dalam dunia hewan tersebut adalah seorang dukun, bukan pakar kesehatan hewan atau dokter hewan yang hebat.

Yang membuat dada Lanang kian bergetar, pakar yang kedua adalah juga orang yang telah dikenalnya; dukun hewan Rajikun. "Gila, betul-betul dunia ilmiah telah berdampingan dengan alam mistik," Lanang memegang dadanya yang getarannya terasa lebih kencang (Rahardjo, 2008: 288).

Keilmiahan ilmu pengetahuan seakan tergeser oleh kekuatan mistik bahkan ketika harus berbicara secara ilmiah tentang suatu penyakit hewan. Ruang ilmiah semacam seminar sebenarnya juga merupakan ruang yang tepat sebagai ruang pembunuhan karakter bagi seseorang. Seperti yang dilakukan oleh dukun Rajikun terhadap dokter Lanang. Kegemaran dokter Lanang dalam melakukan hubungan intim dengan perempuan selain istrinya, dijadikan senjata oleh dukun hewan Rajikun untuk mempengaruhi seluruh peserta seminar dengan mengatakan bahwa dokter Lanang yang menjadi penyebab kematian ribuan sapi tersebut. Hal-hal yang secara ilmiah tidak dapat diterima akal, di tangan dukun Rajikun menjadi seolaholah kenyataan yang tidak terbantahkan kebenarannya. Hal itu dikarenakan pamor dukunnya yang sudah mendapat tempat di hati teman-teman dokter Lanang, pegawai koperasi dan juga para peternak.

"Kekuatan pada dirimu dengan me- 
nyedot kuman dari cairan para wanitalah yang telah menyatu dan kawin silang menjadi Babi Burung Babi Hutan yang telah memangsa ribuan sapi itu!"(Rahardjo,2008: 297).

Dengan berbekal keuletannya untuk meramu kebohongan dan fitnah dengan kedok kemistisan, dukun hewan Rajikun berhasil mencapai tujuannya yakni meyakinkan seluruh masyarakat dan peternak, pegawai koperasi serta para dokter hewan bahwa penyebab kematian ribuan sapi perah tersebut adalah ulah dokter Lanang yang gemar mengoleksi cairan dari para wanita yang ditidurinya. Cairan-cairan hasil sedotan dokter Lanang terhadap para wanitalah yang melahirkan makhluk aneh burung babi hutan penyebab kematian sapi-sapi perah milik para peternak.

Bisik-bisik dan desas-desus ujung dari pertemuan hari itu, Rajikun dan Sukirno telah membuka tabir di balik Burung Babi Hutan yang menjadi tumbal kematian ribuan ekor sapi di seluruh nusantara (Rahardjo,2008: 303).

Setelah melakukan pencarian yang menghabiskan waktu panjang, Dokter Lanang yang merupakan orang berpengetahuan luas meyakini bahwa burung babi hutan yang mendatanginya tercipta dari perpaduan antara ilmu dan klenik atau hal-hal yang mistis. Dengan berbekal keyakinan tersebut, ia berusaha untuk memusnahkan burung babi hutan sebagaimana asal penciptaannya.

"Aku yakin, burung babi hutan merupakan perpaduan antara ilmu dengan klenik." Putri diam dengan mata bertanya (Rahardjo, 2008: 223).

Persoalan mistis yang diusung oleh Yonathan tidak hanya sebatas pada pemikiran adanya makhluk halus buatan manusia. Makhluk tersebut dipercaya sebagai penyebab wabah penyakit pada sapi-sapi perah peternak, tetapi juga pada kepercayaan bahwa ketika seorang istri sedang mengandung, maka suami tidak diperbolehkan melakukan perbuatanperbuatan buruk. Hal ini dikarenakan dampak perbuatan calon ayah tersebut akan menimpa jabang bayi yang masih ada dalam kandungan.

Kekhawatiran terhadap kesamaan nasib seperti yang terjadi pada legendalegenda babi jadi-jadian yang kerap menghantui penduduk daerah itu bisa dihalau suami istri itu. Kandungannya tidak kempes. Bayi di dalamnya pun tidak lenyap. Tidak seperti yang dikhawatirkan bila babi jadi-jadian mengganggu manusia (Rahardjo, 2008: 233).

Kepercayaan serupa juga dapat dilihat dari kutipan di bawah ini.

Oleh karena itu selalu diingatkan, bila telah melakukan hal buruk itu, si orang tua harus mengucapkan "Amitamit jabang bayi!". Tujuannya supaya si bayi dilepaskan dari bahaya yang bisa menimpa. Mereka mengakui sudah melakukan hal ini, dan terbukti betul khasiatnya, walau Lanang sendiri tidak memedulikan hal itu (Rahardjo,. 2008: 234).

Kehidupan masyarakat selalu dibingkai oleh tata nilai. Tata nilai merupakan rujukan pedoman yang digunakan seseorang boleh melakukan sesuatu atau tidak. Suatu kenyataan di masyarakat ketika menemui sesuatu yang buruk dan bertentangan dengan nilai sosial masyarakat akan menghindarinya. Keyakinan masyarakat membawa konsekuensi perilaku individu yang bersangkutan. Namun kenyataannya ada sebagian individu yang tidak memikirkan hal tersebut. Kebudayaan yang dimiliki oleh suatu masyarakat merupakan kekuatan yang tidak tampak (invisible power) yang mampu menggiring masyarakat untuk bersikap dan berperilaku sesuai dengan pengetahuannya (Kurniati, 2007: 53). 
Terbunuhnya makhluk aneh yang dikenal dengan burung babi hutan di tangan Lanang, menjadikan dukun Rajikun terkenal. Pamornya semakin melejit sebagai dukun dan ahli alam raya. Burung babi hutan mati dan tubuhnya sirna. Hal ini sesuai dengan apa yang dipercayai oleh masyarakat bahwa makhluk tersebut adalah makhluk misterius. Kedinamisan hidup ini menempatkan manusia terus gelisah dalam pencariannya (Sariban, 2009: 43). Demikian pula yang dilakukan Rajikun yang berprofesi sebagai dukun yang terus berupaya mencari legitimasi atas kerja yang dilakukan.

Kelegaan yang tersendiri adalah barangkali ini akhir dari teka-teki dari penyakit misterius yang telah merusak hidup mereka dan membuat para peternak kehilangan sapi perah. Benar-benar membekas, apa yang telah dikatakan ahli alam raya, Rajikun (Rahardjo, 2008: 234).

Aspek mistis di atas sebagai sebuah rekayasa yang dibuat untuk mengelabuhi masyarakat atas peristiwa-peristiwa yang ada. Peristiwa tersebut sengaja dibuat untuk mengalihkan perhatian masyarakat terhadap kecanggihan teknologi sehingga memberikan dampak pada keyakinan masyarakat bahwa semua itu sebagai perwujudan mistis. Hal ini terjadi karena pengarang menanggapi situasi yang ada dalam masyarakat, seorang pengarang tidak dapat melepaskan diri dari pengetahuan, emosi, agama, ideologi, dan kepercayaan yang dianutnya (Sungkowati, 2007: 169). Proses kelahiran karya sastra lebih banyak disebabkan oleh dialektika yang terus menerus antara nilai-nilai ideal tertentu pengarang dengan nilai-nilai realitas yang tidak dapat terhindarkan.

\section{SIMPULAN}

Berdasarkan uraian pada pembahasan dapat disimpulkan sebagai berikut. Pertama, pertautan aspek intelektual dalam novel Lanang karya Yonathan Raharjo secara nyata dipengaruhi oleh latar belakang pendidikan pengarang sehingga mampu menghasilkan narasi cerita yang membawa pembaca pada dunia kesehatan hewan meskipun tidak total. Kecerdasan pengarang dalam memadu secara alami fakta sosial sastra dalam novel patut dihargai seolah-olah menjadi sebuah fiksi pengetahuan. Kedua, pertautan aspek mistis dalam novel Lanang terjadi karena kejelian pengarang untuk mencermati budaya masyarakat yang menyakini bahwa mistis sebagai kekuatan sedang berada pada era modern. Realitas dan mistis telah menyatu dengan cara pandang masingmasing, sehingga terkadang terjadi keanehan-keanehan yang tidak masuk akal akan tetapi diyakini kebenarannya.

\section{UCAPAN TERIMA KASIH}

Artikel ini merupakan bagian dari hasil penelitian Fundamental tahun 2013. Ucapan terima kasih disampaikan kepada Direktur DP2M DIRJEN DIKTI KEMENDIKBUD yang telah memberikan kepercayaan dan pendanaan pada penelitian ini. Selanjutnya ucapan terima kasih disampaikan kepada teman-teman sejawat yang telah memberikan kegiatan verifikasi dan triangulasi data penelitian. Selain itu, ucapan terima kasih juga disampaikan kepada Yonathan Rahardjo sebagai pengarang yang telah memberikan informasi yang cukup penting untuk menunjang informasi penelitian serta saudara Kholifah yang telah membantu sebagai tenaga enumerator dan teman diskusi pada penelitian ini.

\section{DAFTAR PUSTAKA}

Anwar, Ahyar. 2012. Teori Sosial Sastra. Yogyakarta: Ombak.

Faruk. 2001.Beyond Imagination. Yogyakarta: Gama Media

Faruk. 2013. “Tantangan Tahun 2000-an bagi Sastrawan". Makalah disampaikan pada Temu Pengarang di Univer- 
sitasitas Muhammadiyah Malang, 13 November 2013

Garbiz, Alimudin. 2013. “Mistisisme dalam Kehidupan Masyarakat". Http:// sosbud.kompasiana.com/2013/02/15/ html. Diakses 25 Oktober 2012.

Kurniati, Ai. 2007. “Identitas Kultural Dayak dalam Sajak-Sajak H.A. Badar Sulaiman Usin". Semiotika.Vol 8.1 Januari-Juni 2007. Jurnal Sastra Indonesia Fakultas Sastra Universitas Jember bekerjasama dengan HISKI, HPBI, dan MLI.

Rafiek, M. 2010. Teori Sastra Kajian Teoridan Praktik. Bandung: Refika Aditama

Ratna,Nyoman Kutha 2008. Postkolonialisme Indonesia Relevansi Sastra. Yogyakarta: Pustaka Utama

Ratna, Nyoman Kutha. 2013. Paradigma Sosiologi Sastra . Yogyakarta: Pustaka Utama

Saraswati, Ekarini. 2003. Sosiologi Sastra. Malang UMM Press
Sariban. 2009. “Proses Menjadi dalam Novel Tarian Setan Karya Saddam Hussein dan Siddhartha Karya Hermann Hesse". Atavisme Jurnal Ilmiah Kajian Sastra,Vol 12 No.1 Juni 2009. Departemen Pendidikan Nasional Sekretariat Jenderal Pusat Bahasa Jakarta.

Sungkowati, Yulistin. “Kerudung Santet Gandrung: Simbol Perlawanan terhadap Kaum Santri Banyuwangi". Diksi, Vol. : 14 No.2 Juli 2007. Fakultas Bahasa dan Seni Universitas Negeri Yogyakarta.

Rahardjo, Yonathan. 2008. Lanang. Jakarta: Pustaka Alvabet

Rahardjo, Yonathan. 2013. "Penciptaan di Belantara Korupsi Sejarah Sastra". Makalah Temu Pengarang di Universitas Muhammadiyah Malang, 13 November 2013 